91

5）市原通敏：術擊振 り試臨，第 1 報一第 5 報，日本 栱械学会誌，昭和 7 年 7 月，昭和 10 年 2 月 6 月

6) Siebel, $E$. and $E$. Fangmeier: Versuche über den Formänderungswiderstand und den Formänderungsverlauf beim Warmwalzen, Mitt. K.W.I., 1930, pp. 225 244

7) Pomp. A. and W. Lueg: Walzversuche an kohlenstoff und silizium-legierten Stählen,
Mitt. K.W.I., 1933, pp. 81 97

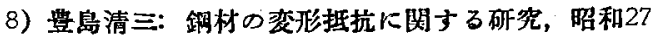
年 1 月，八幡製鉄技術矿究所報告

9）大幸喜三郎：火砲の安全係数について, 火兵学会 誌, 昭和 18 年 1 月, pp. 301 326

10) Ludwik, P.: Element der technologischen Mechanik, 1909

11) Holloman, $J$. H.: Tensile Deformation, Trans. AIME, $1945, \mathrm{p}, 268$

\title{
高溫度に於けるスケールの浸透についで
}

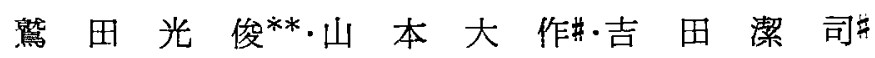

\section{ON SCALE PENETRATION IN STEEL AT HIGH TEMPERATURES}

\section{Mitsutoshi Washida, Daisaku Yamamolo and Kiyoshi Yoshida}

Synopsis:

When the iron and steel are heated in the oxidizing atmosphere at high temperature, the oxidation scale penetrates into matrix right below the surface scale. The authers studied on the phenomena of this penetration under various conditions using a rimmed steel (C $0.08 \%)$.

Heating conditions: temperature $1150^{\circ} \mathrm{C} \sim 1350^{\circ} \mathrm{C}$, atmosphere $\mathrm{O}_{2} 5 \sim 50 \% \mathrm{~N}_{2}$ Bal.

$$
\mathrm{CO}_{2} 5 \sim 50 \% \mathrm{~N}_{2} \text { Bal. }
$$
time $30 \mathrm{mn} \sim 2 \mathrm{~h}$

In order to compare the individual results each other, the depth of penetration and the size of penetrated scale were measured and those results were as follows:

1) The granular scales penetrated in considerable depths even in the atmoshere of only $\mathrm{N}_{2}$ gas, and this penetration depth was nearly the same value gained when it was mixed with gases of $\mathrm{O}_{2}$ or $\mathrm{CO}_{2}$

2) Penetration of scale was greatly affected by the heating temperature:- the higher the temperature, the deeper the depth and the larger the size of the penetrated scales.

3) Heated above $1300^{\circ} \mathrm{C}$, huge scale appears and was remarkable under such conditions as $\mathrm{O}_{2}$ gas was added. Therefore it was evidenced that the penetration of scale took part in the defect of the over-heating.

4) The color of granular penetrated scales were light-bluish-gray and that of the huge scales were composed by both light-and dark-bluish-gray.

5) If the heating condition changed, then the thickness of surface scales increased, and huge penetrating scale was produced even at below $1300^{\circ} \mathrm{C}$.

\section{I. 緒 言}

鋼材を酸化性䨢团気中にて高温度に加熱すると，選択 酸化により非酸化性元素 $(\mathrm{Ni}, \mathrm{Cu}, \mathrm{As})$ がンケール層直 下に濃化し，熱間加工後に久陷として現われることは既 に知られているが, 最近, 亳温加熱によりスケール閻苴下

* 昭和 29 年 10 月本会满演大会にて発表

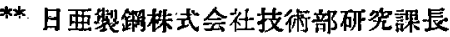

吉同上技衍部䂨究課
の地鉄にスケールか浸透し，その結果熱間加工後に微細 な萑面疪を生しることを認め45) 非酸化性元菜の浱化と 共にスケールの浸透は加熱の影響として重要な問題とな つている. 勿論非酸化性元素の含有量によりスケールの 浸透の程度か左右されるかH.Buchholtz の然験引によれ ば $1250^{\circ} \mathrm{C}$ 近くになると枌筫の差よりも温度の影留が明 らかに認められスケールの浸透は基しくなるといつてい る。㕛田島氏らによれば，蓄面濃化により熱間脆性を起 すとされた估険限界を迸かに下迴つていてもスヶールの 
浸透による影㻰を認めている・

スケールの浸秀は加熱雾国気中の $\mathrm{O}_{2}$ ぶスケールを浸 透し,地鉄の表面から内部への $\mathrm{O}_{2}$ の昖散によつて Oxi・ de の Particle が地鉄に沈殿するものでありり加熱条 件としては，加熱雾囲気，温度，時間に影響され゙

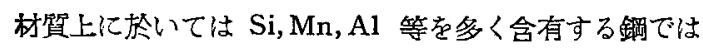
之等が $\mathrm{Fe}$ より酸素に対する親和力が大であるので，ス ケールの浸透は甚しく298) $\mathrm{Ni}, \mathrm{Cr}$ 等学多量に含有す る18-8 ステンレス銅に䍅いては，生成されるスケール か耐酸化性であるため浸透は僅かであると考光られる。

スケールの浸透に及ばす元素の影暗の問題は重要であ るが，本報告に於いては，先ず加熱条件を種々变化させ てスケールの浸透の形態をリムド鋼について確めた実 験結果につき述べ，終りに二，三の鋼種につき浸透の差 異它比較する。

\section{II. 実 験 万 法}

実験装置は Fig. 1 に示す如く，ガス坾槽，加熱妒， 排気の3 部分よりなり，炉心管には耐熱管焼結品 (50 $\mathrm{mm} \phi \times 1000 \mathrm{~mm})$ を用い，耐熱管の活損と試片保持の ため，中央に試片支持管 $(35 \mathrm{~mm} \phi \times 100 \mathrm{~mm})$ を插入 し試片を置いた。

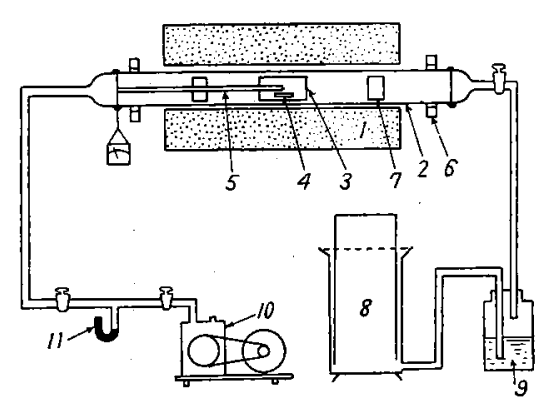

1. Electric furnace

2. Sinter refractory tub3 (50mm $1 \times 1000 \mathrm{~mm}$ )

3. Specimen supporting tube ( $36 \mathrm{~mm} \phi \times 100 \mathrm{~mm})$

4. Specimen 5. Thermocouple

6. Ring cooler

7. Baffles

8. Gas storage tank 9. $\mathrm{B}_{2} \mathrm{SO}_{4}$

10. Vacuum pump 11. Manometer

Fig. 1. Apparatus

始め $\mathrm{N}_{2}$ ガフ中にて加熱速度 $9^{\circ} \mathrm{C} / \mathrm{mn}$ にて加熱し， 実験温度に達すれば真空ポンプにて排気して所要のガス. 々置換し一定時間保持後再び排気し $\mathrm{N}_{2}$ ガスと置換後师 冷する・試片はリムド鋼 (C 0.08, Si tr, Mn 0.45,

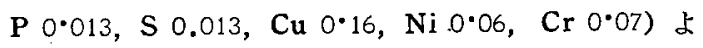
り $24 \mathrm{~mm} \phi \times 5 \mathrm{~mm}$ に切削し, エメリーペーベー2/0迄

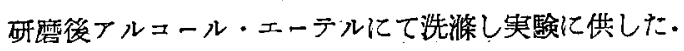

熱処理後の試片は直径方向に切断し，その断面の加熱時 の上面を検鏡䇢所とした。

加蓺条件注，加熱温度 $1150^{\circ} \mathrm{C}, 1250^{\circ} \mathrm{C}, 1300^{\circ} \mathrm{C}$,

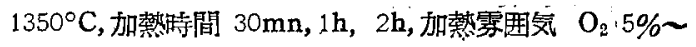
$50 \%$ (残余は $\mathrm{N}_{2}$ )， $\mathrm{CO}_{2} 5 \%$ - $50 \%$ (殘余は $\mathrm{N}_{2}$ ) にて 処理を行つた。浸透の程庭を比較する方法としてスケー ル層直下の地鉄の蓄面よりスケールの浸透した深さをメ 400 にて测定し，浸透の梁さを $\mathrm{mm}$ にて示し，その浸 透した粒状のスケールの大きさは，スケール層直下の地 鉄表面より $0.05 \mathrm{~mm}$ 迄の深さに浸透したスケールの粒 の直径の平均値で,粒の大きさをいで示す.良つて以下文 中にて粒が大，小という事は $0.05 \mathrm{~mm}$ 迄に浸透した粒 状のスケールの事を意味する・尚加埶温度を $1300^{\circ} \mathrm{C}$, $1350^{\circ} \mathrm{C}$ にしたの优過熱による浸透の程度学䄼討する為 である・

\section{III. 実 験 結 果}

1) 加熱温度について

$1150^{\circ} \mathrm{C} \sim 1350^{\circ} \mathrm{C}, \mathrm{O}_{2} 16 \%+\mathrm{N}_{2} 90 \%$ 1h 加爇した 結果を Fig. 2 に示す. 速に示卞如く加熱温度の上早々 共に浸透の潹さを增し, 特に $1300^{\circ} \mathrm{C}$ 以上に於いては顕 著で, 樑さは急激に増し，粒の大きさも同様に急激に大 きくなつている (写真 1 ー 3参照)

2) 加熱雾国気について

i) $\mathrm{N}_{2}+\mathrm{O}_{2}$ ガス

$\mathrm{N}_{2}$ ガスに $\mathrm{O}_{2}$ ガスを 5\% 50\% 添加して $1250^{\circ} \mathrm{C}$, $1300^{\circ} \mathrm{C}, 1350^{\circ} \mathrm{C}$ 亿 $\mathrm{h}$ 加熱した綪果を Fig. 3 に示市. $1250^{\circ} \mathrm{C}$ に加熱したものは $\mathrm{O}_{2} \%$ の堌すに従つて浸透の 樑さを増大するが, $15 \%$ 上上では逆に樑さを減じると共 に粒の大きさ沙大になる. $1300^{\circ} \mathrm{C}, 1350^{\circ} \mathrm{C} に$ 於いては 10\% 以上から同様に梁さる減じ $1300^{\circ} \mathrm{C} に て は 30 \%$, $1350^{\circ} \mathrm{C}$ では15\%ににた大なスケール在生成す泻真 10,11 参照） $\mathrm{O}_{2} 10 \%$ 迄は $1300^{\circ} \mathrm{C}$ ह $1350^{\circ} \mathrm{C}$ との 浸透の深さの差違が無い事は $1350^{\circ} \mathrm{C}$ 加熱のものはFeO の愹融点 $1377^{\circ} \mathrm{C}$ 附近であるためスケールリング甚しく 揮散した為と思われる。

ii) $\mathrm{N}_{2}+\mathrm{CO}_{2} \pi$

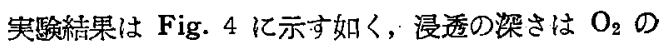
場合より全般に大で， $\mathrm{CO}_{2} \%$ が増加しても急激に減少 せず， $1250^{\circ} \mathrm{C}$ に於いては $\mathrm{O}_{2}$ の場合之同樣に $20 \%$ 迄 は浸透の梁さを增し，それ以上では浸透の梁さは僅かに 減少し，粒の大きさは大きくなつている・ $1300^{\circ} \mathrm{C}, 1350$

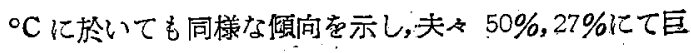
大なスケールを生成する.図に示可如く浸透した粒の大 


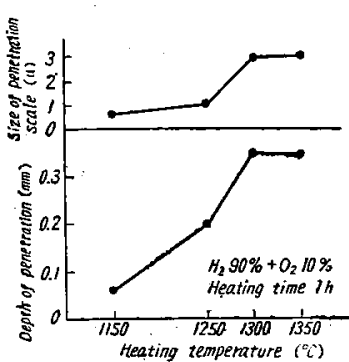

Fig. 2. Effect of heating temperature on the penetration of scale.

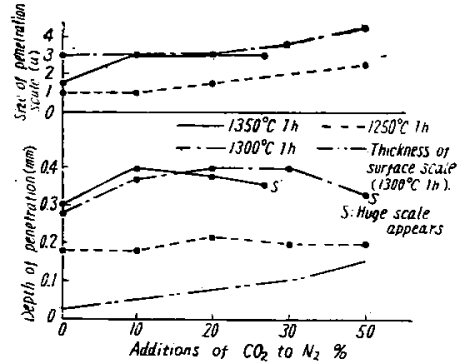

Fig. 4. Effect of atmosphere on the penetration of scale $\left(\mathrm{N}_{2}+\mathrm{CO}_{2}\right)$

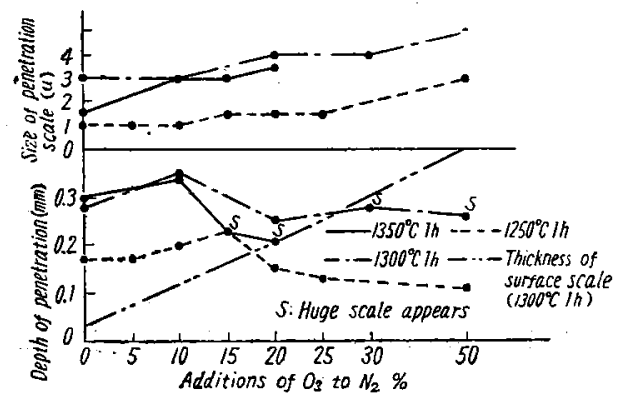

Fig. 3. Effect of atmosphere on the penetration of scale $\left(\mathrm{N}_{2}+\mathrm{O}_{2}\right)$

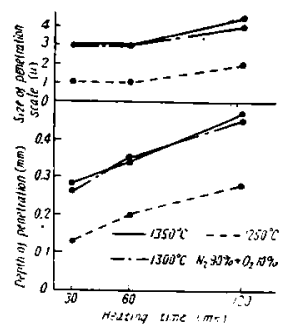

Fig. 5. Effect of heating time on the penetration of scale

生成され易いてとが判る。 加熱条件によつて表面スケ ールの厚さは变化するが， 表面スケールの薄い間は酸 化速度が大で粒状のスケー ルが浸透し，スケールが厚 くなると, 酸化速应を減し 宸素の外方的の㧨散速度が 大になり，脱炭を促進する 結果，巨大なスケールを生 成するものと考元る。よつ て，加熱条件变えること により、スケールの厚みを大にすると巨大な スケールな生成すると推定され，以上行つ た笑験により巨大なスケールを生成しなかつ た $1300^{\circ} \mathrm{C} \quad \mathrm{O}_{2} \quad 10 \%$ のもの艺笑駼始め上り $\mathrm{O}_{2} \quad 10 \%$ のガスを $15 \mathrm{cc} / \mathrm{mn}$ の济速にして 他の条件を同一にして加熱を行つたが予想通 り巨大なスケールを生成した（この場合のス ケールの厚み $0.56 \mathrm{~mm}$ ) 合加熱时間,加熱速 度等を变化すれば更に低い温展にてを巨大な スケールを生成する (Photo. 9 参照)

4）スケールの地鉄に浸透する形態

スケール層直下の地鉄に浸透したスケールは粒状の淡

きさ脑 $\mathrm{O}_{2}$ の場合と大差なく，只，粒か $\mathrm{O}_{2}$ の場合は混 粒を呈しているが， $\mathrm{CO}_{2}$ の場合は均一な粒方浸透して いる. $1300^{\circ} \mathrm{C}$ に於いて測定した表面スケールの厚さを Fig. 3，4 に示してあるが， 10\% の場合を例にとると $\mathrm{O}_{2}$ の場合 $0.12 \mathrm{~mm} \mathrm{CO}$ は $0.05 \mathrm{~mm}$ で, 厚さが $\mathrm{O}_{2}$ の場合より薄い為スケール中のガスの浸透か容易である 故浸透の深さが大であると思われる：

3）加熱時間について

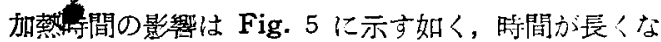
ると深さき增し粒の大きさは $1 \mathrm{~h}$ 上上で急激に大きく なつている. $1300^{\circ} \mathrm{C}, 1350^{\circ} \mathrm{C} に 2 \mathrm{~h}$ 加熱しても梁さ を増し，粒が大きくなるので巨大なスケールを生成し ないのは，実験方法としてがスを封入して加熱を行つて いる故加熱時間が長くなつても顕著な影留を現わさな W.

以上の垁験結果より，スケールの浸透は，先ず加熱温 度に著しく影響され，次いで加熱時間，加熱雾再気であ

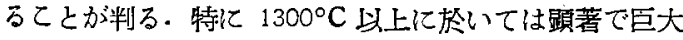
なスケールを生成する。粒状のスケールの浸透は $\mathrm{N}_{2}$ 力 スのみの場合にても相当量唚透し， $\mathrm{O}_{2}, \mathrm{CO}_{2}$ 何礼の場 合にても大差なく，只巨大なスヶールは $\mathrm{O}_{2}$ の場合には 青灰色を呈し，加熱温度が高く，加熱時間の大なるもの 程「粗」に分布し，粒の大きさも大である. Photo.1 3 に示す如く加熱温度が上昇すると粒は大きくなり「粗」 に分布している. 粒が大きくなり，浸透の梁さが減じて くると Photo.7 に示す如くスヶール層直下に稍々大粒 のものか潵在する．侗更に粒が大きくなると，淡翌灰色 濃青灰色の二色を呈し, Photo.8 に示卞如く地鉄の表面 加ら一定の梁さに並列して存在する.Photo.10,11は $1300^{\circ} \mathrm{C} に 20 \% \mathrm{O}_{2}, 50 \% \mathrm{O}_{2}$ にて夫々生成した巨大 なスケールを示し，大きさは $0.1 〜 0.2 \mathrm{~mm}$ 程是にて 2

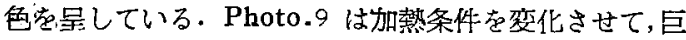
大なスケールを生成した例であり，加熱速度は従来と同 一で只 $1000 \mathrm{C} \mathrm{N}_{2} 80 \%+\mathrm{O}_{2} 20 \%$, $1 \mathrm{~h}$ 酸化を行い更に $1250^{\circ} \mathrm{C}, \mathrm{N}_{2} 50 \%+\mathrm{O}_{2} 50 \%, 1 \mathbf{h}$ ，処理を行つたもので あり (吻論谷処理の前後の霝囲気は $\mathrm{N}_{2}$ のみ) Photo.7 と比べて浸透の差違を明確に示している. 高温度にて生 成した巨大なスケールは地鉄表面から浸透しているが， 低温度にて生成したものは地鉄表面から一定の間隔をお いて並列に存在している．台浸透したスケールと結晶粒 界との関係は，粒状のスケールは結晶粒界に舤関保に浸 

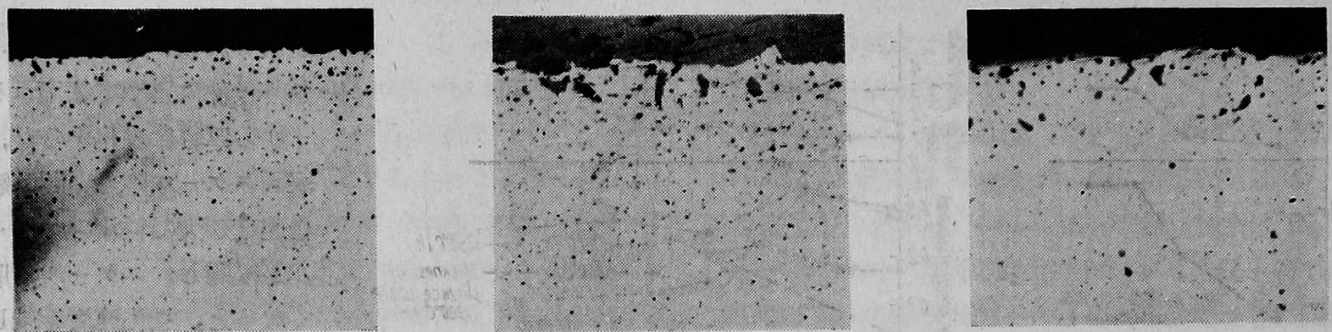

Photo. 1. $1250^{\circ} \mathrm{C} \mathrm{N} \mathrm{N}_{2} 90 \%+\mathrm{O}_{2} 10 \%$ Photo. 2. $1300^{\circ} \mathrm{C} \mathrm{N}_{2} 90 \%+\mathrm{O}_{2} 10 \%$
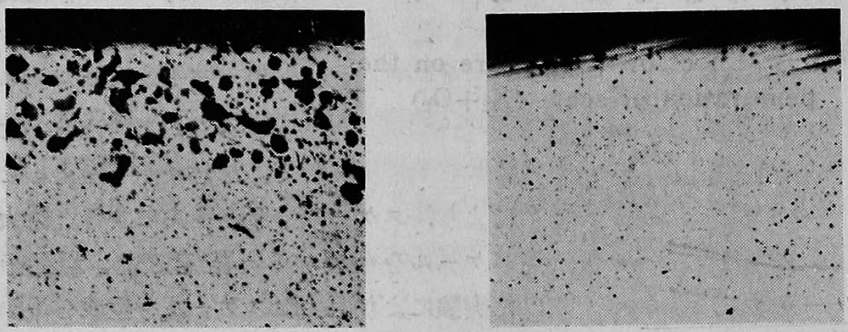

Photo. 4. $1250^{\circ} \mathrm{C} \quad \mathrm{N}_{2} 90 \%+\mathrm{O}_{2} 10 \%$ Photo. 5. $1250^{\circ} \mathrm{C} \quad \mathrm{N}_{2} 90 \%+\mathrm{O}_{2} 10 \%$

Photo. 3. $1350^{\circ} \mathrm{C} \mathrm{N} \mathrm{N}_{2} 90 \%+\mathrm{O}_{2} 10 \%$
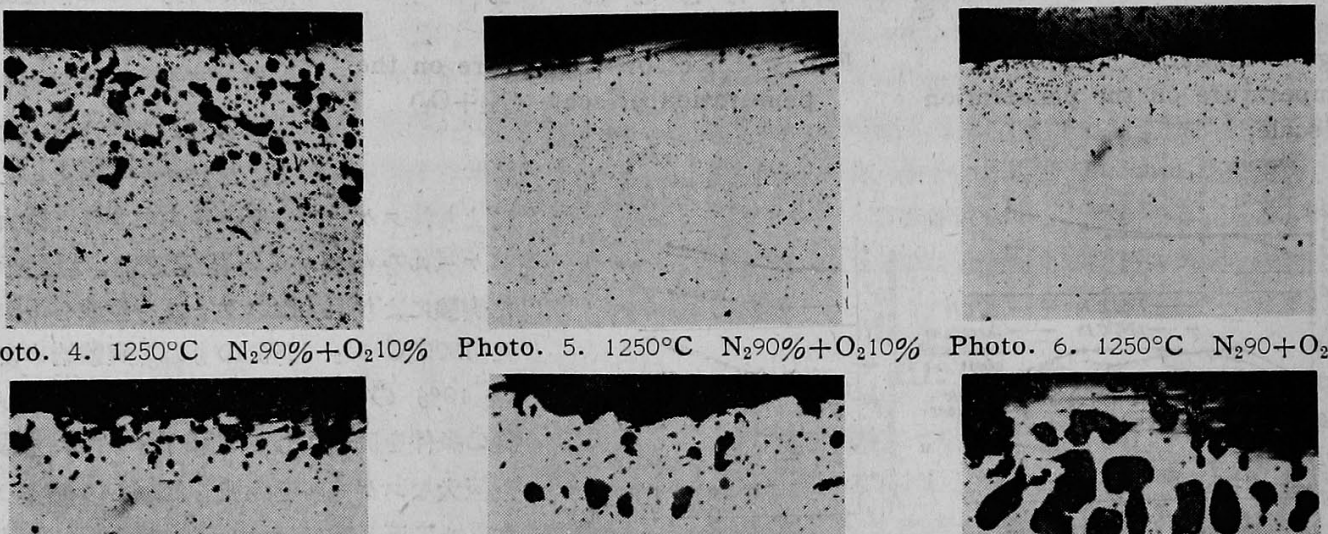

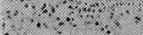

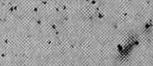

Photo. 6. $1250^{\circ} \mathrm{C} \quad \mathrm{N}_{2} 90+\mathrm{O}_{2} 10 \%$

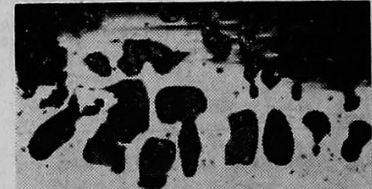

Photo. 7. $1250^{\circ} \mathrm{C} \quad \mathrm{N}_{2} 50 \%+\mathrm{O}_{2} 5$

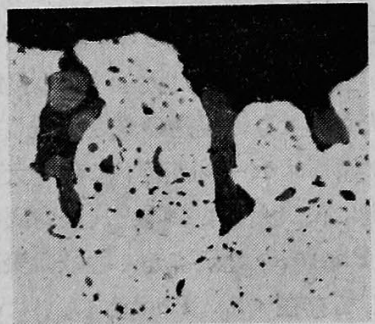

Photo. 8. $1250^{\circ} \mathrm{C} \quad \mathrm{CO}_{2} \quad 100 \%$

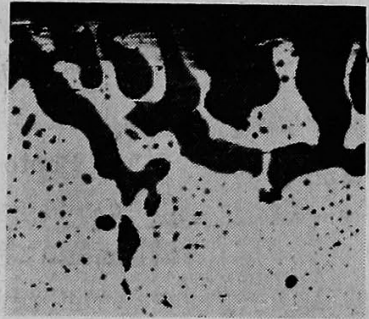

Photo. 9. $1000^{\circ} \mathrm{C} \quad \mathrm{N}_{2} 80 \%+\mathrm{O}_{2} 20 \%$ $1250^{\circ} \mathrm{C} \quad \mathrm{N}_{2} 50 \%+\mathrm{O}_{2} 50 \%$

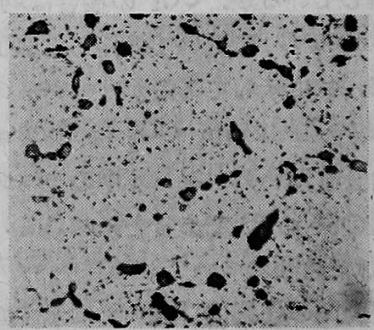

Photo. 10. $1300^{\circ} \mathrm{C} \mathrm{N} \mathrm{N}_{2} 70 \%+\mathrm{O}_{2} 30 \%$ Photo.11. $1300^{\circ} \mathrm{C} \mathrm{N} \mathrm{N}_{2} 50 \%+\mathrm{O}_{2} 50 \%$ Photo. 12 . $125^{\circ} \mathrm{C} \mathrm{N} \mathrm{N}_{2} 90 \%+\mathrm{O}_{2} 10 \%$

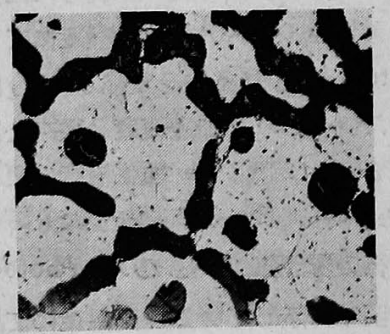

Photo. 13. $1300^{\circ} \mathrm{C} \mathrm{N}_{2} 50 \%+\mathrm{O}_{2} 50 \%$

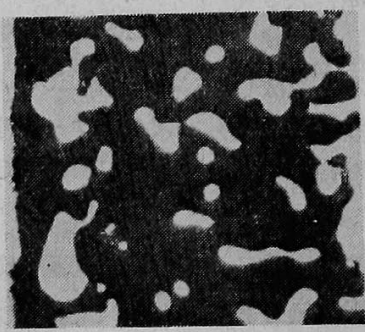

Photo. 14. $1350^{\circ} \mathrm{C} \mathrm{O}_{2} 100 \%$
Heating time $1 \mathrm{~h}$

Photo. $1 \sim 11,13,14 \times 300$

(1/2 contracted)

Photo $12 \times 200:(1 / 2$ contracted $)$

Forms of Penetrated Scales 
透しており，巨大なスケールは結晶粒界に大きく浸透し ている.

以上述べた事は断面の检鏡結果であるが，表面のスケ ールを虽いで，スケール層㨁下の面を榆鏡した処Photo 1 に示す様に粒状のスケールが分布しているもののス ケール層直下の検鏡結果は Photo. 12 の如く粒状の

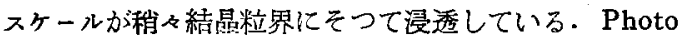
110如く巨大なスケール在生成したるのは Photo.13に 示す如く結晶粒界に大きく浸透し，粒状のスケールか結 晶粒内に存在する・浸透したスケールの箼青灰色を呈し 污の主 Wüstite，䢠青灰色は Magnetite で6) Wüstite 方师冷時に $4 \mathrm{FeO} \rightleftarrows \mathrm{Fe}+\mathrm{Fe}_{3} \mathrm{O}_{4}$ 反応により Magnetiteになつたものであり，二色を是するものは末だ 上記の反応か十分に行われなかつた為である゙。

次に浸透したスケールの硬度を Photo.11 の巨大な スケールについて測定を行つたが，澺青灰色のちのは Hv553,淡青灰色は Hv475 で, Photo.13 のスケール層 直下の面に浸透したスケールは Hv 724 でPhoto.14(断 面を棁鏡したもの）のスケールの便度 Hv 630〜1000で 地鉄直上のスケールの硬度が上年していることは略々明 らかである.Photo.14 にて判る如く層状を旺しだ装面 スケールを生成しているか，とれは强酸化性雾再気中で 長時間加蓺すると非酸化性元素が濃化するためで，硬度 の上算をこの為であろう.

5) 2, 3 の鋼種についての浸透の比較

上上述べたリムド鋼の実験結果と比べる意味にて2，

3 の鎆種について行つた。

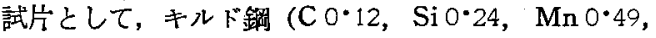
$\mathrm{P} 0 \cdot 024, \mathrm{SO} 015, \mathrm{Cu} 0 \cdot 30$, Ni $0 \cdot 10, \mathrm{Cr} 0 \cdot 10)$ 弾丸材 (C 0.45, Si 0.23, Mn 0.80, P 0.025, S 0.020, Cu 0.22, $\mathrm{NiO} 07, \mathrm{Cr} 0.06)$ ステンレス鋼 (18-8) の3つ について $1250^{\circ} \mathrm{C} \mathrm{O}_{2} 10 \% 1 \mathrm{~h}$ 加熱して比較を行つた。

Photo.4はキルド鎆で，浸透の㳭さは本実験に用いた リムド鋼と大差ないが，地鉄表面に比較的大きな粒状の スケールが存在し，浸透の程度は著しく，Si の影響と 思われる.Photo.5 は弾丸材で浸透の潹さは大差なく， 粒状のスケールが密に分有している． Photo.6 はステ
ソレス鋼で浸透の深さはリムド鋼の $1 / 4$ 程㛺にて，浸透 し難いことを示している。

\section{IV. 結訔}

以上実験結果より

1）スケールの浸透は加熱温度に著しく影辝され，温 度の高い程深く，スケール壓直下の粒も大である。

2）粒状のスケールは $\mathrm{N}_{2}$ ガスのみの埸合にても相当 量浸透し， $\mathrm{O}_{2}, \mathrm{CO}_{2}$ にて 若干の差はあるか略及同程 度に浸透している。

3） $1300^{\circ} \mathrm{C}$ 以上に加熱するとスケール凰直下に巨大 なスケールを生成し, 特に $\mathrm{O}_{2}$ の埼合生成され易く, 過

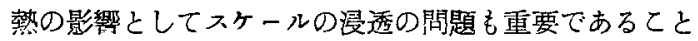
が判る。

4）浸透したスケールは淡青灭色の粒状を是し，粒が 大きくなると溜青灰色を是したすのとの二色な呈する。

5）加熱条件を变化し，生成される表面スケールの厚 さを大にすれば $1300^{\circ} \mathrm{C} よ り$ 低い温度に於いても巨大な スケールを生成する。

本実験により，リムド鋼を目いてのスケールの浸透の 形態が略々明らかとなつたので，実駼結果の（5）では リムド鋼との比較程度に述べたに過ぎないが，更に浸透 に及ばす元素の影留については实験を進めている。

終りに本研究に当つて懇切なる御指導を賜つた技術部 長工学㩐土垣内富土雄氏に厚く謝意を表します。

\section{（昭和 29 年 12 月寄稿）}

交献

1) C. L. Meyette: Tr. A.I.M.E. (1948) 176201

2) A. Preece: J.I.S.I. (1944) 1253

3) H. Buchholtz: St u. Ei (1953) 204

4）下因，噯野：鉄之锹，40（1954） 420

5) 田島, 北川: ", 40 (1954) 233

6) 沢村, 盛: " , 38 (1952) 31

7) M. H. Davies: Journal of Metal (1951) 10

8) S. L. Gertsman: Iron Age (1952) 14136

9) R. Ward: Tr. A.I.M.E (1945) 162, 141

10) L. S. Darken: Tr. A.I.M.E (1942) 150, 152 